InOedia $\quad \begin{aligned} & \text { InMedia } \\ & \text { The French Journal of Media Studies }\end{aligned}$

9.1. $\mid 2021$

Film and TV-induced Tourism: Some Contemporary

Aspects and Perspectives

Janet Kraynak, Contemporary Art and the Digitization of Everyday Life

University of California Press, 2020, 304 pages

\title{
Antoine Simms
}

\section{(2) OpenEdition \\ Journals}

Electronic version

URL: https://journals.openedition.org/inmedia/2879

DOI: 10.4000/inmedia.2879

ISSN: 2259-4728

Publisher

Center for Research on the English-Speaking World (CREW)

Electronic reference

Antoine Simms, "Janet Kraynak, Contemporary Art and the Digitization of Everyday Life", InMedia [Online], 9.1. | 2021, Online since, connection on 08 February 2022. URL: http://journals.openedition.org/ inmedia/2879 ; DOI: https://doi.org/10.4000/inmedia.2879

This text was automatically generated on 8 February 2022

(c) InMedia 


\section{Janet Kraynak, Contemporary Art and the Digitization of Everyday Life}

University of California Press, 2020, 304 pages

Antoine Simms

\section{REFERENCES}

Janet Kraynak, Contemporary Art and the Digitization of Everyday Life, University of California Press, 2020, 304 pages

1 Data surveillance, election tampering, censorship scandals and hate speech... the reality of today's internet seems far removed from its early promises of a progressive digital utopia. Though Silicon Valley tech companies still cultivate the romantic image of the internet as a space that can bring about our collective emancipation through connectivity, it seems this facade is wearing thin. Behind this rosy rhetoric hide giant neoliberal corporations engaging in surveillance capitalism and their social media platforms, which, rather than building communities, encourage distraction, narcissism, bigotry and the distrust of science and journalism. As a consequence, the internet may have paradoxically grown to become one of the biggest threats to democracy.

2 How, then, can progressive art maintain its traditional role of counter-power? Can it still participate in the elaboration of a counterpolitical public sphere, considering that the digital has already contaminated all aspects of our everyday lives? Such are the central questions addressed in Contemporary Art and the Digitization of Everyday Life (University of California Press, 2020), the latest publication by Janet Kraynak, Senior Lecturer in the Department of Art History and Archeology at Columbia University.

Running counter to the idea that digital technology is merely a neutral tool, the book posits that it is a social form and a political medium informed and shaped by biases and ideologies that reinforce preexisting systems of inequality. Through close readings of artworks spanning from the late 1960s, the 1990s and the aughts, it is thus able to reveal and question how the strategies present in the digital realm seamlessly coincide 
with those of the contemporary art world. In doing so, the author puts an end to what has long been a blindspot in the field of art history criticism.

Chapter 1 touches on the concept of networks and how they relate to both the digital and art world. Christian Philipp Müller's 1993 photo series Illegal Border Crossing serves to illustrate an optimistic take on networks, symptomatic of the early days of the private internet and the new globalist prospects it offered. Drawing a comparison with the more recent works of Bouchra Khalili (The Mapping Journey Project, 2016) and Candice Breitz (Love Story, 2016) dealing with the 2015 refugee crisis, Kraynak is able to bring to light a shifting perspective regarding the perverse consequences of what she calls network effects, which concentrate power in the hands of the already powerful.

Chapter 2 focuses on the works of Philippe Parreno and Pierre Huyghe which both formally and thematically explore the notion of collaboration. Kraynak reveals how their practices echo those of the digital, specifically regarding their reliance on the idea of the "hive mind", a wisdom of the crowds theorized by Kevin Kelly. Such collective practices, though seemingly democratic, are shown to produce non-inclusive power dynamics which blur the line between viewer and participant, work and play, productive and non-productive labor. What is more, these systems often rely on affective labor, which is traditionally affiliated with female forms of work, thus making women more likely to be exploited or alienated by these systems.

6 Chapter 3 further explores the notion of collaboration, this time in regard to the changing status of the museum in an era of surveillance capitalism. Comparing Olafur Eliasson's 2003 The weather project with Bruce Nauman's 1973 Yellow Room, Kraynak argues that the museum is increasingly becoming an extension of the digital world, reprogramming its visitors into users and offering them pleasurable therapeutic experiences where discomfort is anathema. Among the negative consequences of such a paradigm shift, the author notes that certain works undergo revisionist readings. Such is the case of Yayoi Kusama's Infinity Mirror Rooms, which though initially tied to sixties psychedelic culture, has now become a place for museumgoers to interact through the use of selfies.

7 Chapter 4 deals more specifically with the topic of marginalization on the basis of race. Camille Henrot's 2013 video Grosse Fatigue, which aims to tell the history of the universe through Google search, serves here to showcase the pitfalls of the modular systems found in computers and their "lenticular logic". Kraynak notes that in order to process complex information, computer softwares and search engines fragment information and favor dominant systems. In Grosse Fatigue, the decontextualized presence of unnamed pictures of African tribal peoples serves as an illustration of this logic. The marginalized are sidelined and their political power is contained and fragmented.

Chapter 5 is an additional reflexion on the topic of racism and technology, using Glenn Ligon's 2015 installation at the Venice Biennale as the main object of study. This work re-examines Steve Reich's 1966 piece Come Out which exploits the musical quality of a recording of one of the six African American youths wrongly committed for murder in the infamous Harlem Six trial of 1965 . Through a cross-generational dialogue with Reich's work, Glenn Ligon is able to re-contextualize and re-politicize the words of the youth whose voice was silenced. Questioning John Cage's prediction that technology, through techniques of recording and amplification, would bring about attention to all sounds and the impossibility of silence, Kraynak thus argues that new technology, while anticipating an ideal future, can also, in the process, dismiss the social realities of 
the past and present day, thus perpetuating political injustices. The book does not offer clear solutions as to how progressive art could offer alternatives to the hegemonic power of the digital. It does however end with a call to collective, voluntary inservitude.

9 All in all, Contemporary Art and the Digitization of Everyday Life makes for a highly informative and stimulating read. Though the dense critical apparatus may appear daunting to the average reader, it serves a true purpose of clarifying and elevating the author's discourse. The lavishly illustrated chapters, offering deep dives into the works of carefully selected artists, provide a valuable insight into the state of contemporary art and its evolution over the past sixty years. Though the body of works under study might at first prompt surprise, as most are not bound to digital media per se, this idiosyncratic quality only helps emphasize the author's initial claim that digitization isn't limited to a medium, but that it is a social and historically evolving form that has shaped all aspects of our lives.

Ultimately, the author's radical skepticism regarding technology, far from being that of a closed-minded luddite, acts as a refreshing invitation for debate. After reading the book, one may indeed wonder how new evolutions in the field of the digital, like the nascent blockchain technology and its promises of a truly decentralized "net 3.0", could perhaps nuance the author's views on the necessarily centralizing quality of networks, or if the recent development of NFTs (Non Fungible Tokens) in the field of contemporary art could change her stance on the decommodification of the art object in the digital realm. As always, such is the challenge (both exciting and frustrating) of writing about new media: the technology may have gone through leaps and bounds before the writer's ink has even had time to dry.

\section{AUTHORS}

\section{ANTOINE SIMMS}

Université Paris Ouest Nanterre 